\title{
Wars and Military Conflicts of the XXI Century in the Context of the Strategic Interests of the United States
}

\author{
Roman V. Penkovtsev ${ }^{1}$ \& Natalia A. Shibanova ${ }^{1}$ \\ ${ }^{1}$ Kazan (Volga Region) Federal University, Kazan, Russia \\ Correspondence: Roman Vladimirovich Penkovtsev, Kazan (Volga Region) Federal University, Kremlyovskaya \\ street, 18, Kazan 420008, Russia. E-mail: Roman.Penkovtsev@kpfu.ru
}

\author{
Received: April 14, 2015 Accepted: April 20, 2015 Online Published: April 27, 2015 \\ doi:10.5539/jsd.v8n4p164 URL: http://dx.doi.org/10.5539/jsd.v8n4p164
}

\begin{abstract}
The problem under investigation concerning the phenomenon of war is in the center of attention of scientific thought in the field of international relations. The article is aimed at studying the specifics of wars and military conflicts in the modern world which take place under the indirect or direct participation of the United States. The leading approach to the study of this problem is a systematic approach that allows an integrated use of a variety of scientific methods and techniques. The main results of the study indicate that the complexity of types and structure of modern wars and military conflicts make it difficult to resolve them. However, determining the positions and interests of all participants (direct and indirect) and, above all, the identification of strategic interests of the United States is necessary for the effective resolution, prediction and prevention of most contemporary conflicts in the international arena. The materials of article Submissions may be useful for use in the educational process, as well as in the preparation of educational, methodical and scientific literature, as it contains the theoretical principles and a set of specific proposals to improve the post-Cold War international system.
\end{abstract}

Keywords: war, military conflicts, international security, international relations, world politics, the United States, Iraq, Afghanistan, the color revolutions

\section{Introduction}

It is known that military conflicts, including the wars, being a form of interaction between "actors" in international relations, contribute to the destabilization of international relations and lead to various kinds of damage, and sometimes casualties. A comprehensive study of the nature of these phenomena, taking into account the strategic interests of the United States can help the international community to increase the effectiveness of efforts to resolve armed conflicts and to improve the system of international relations.

The completion of the "Cold War", a complex non-military conflict, combining ideological, geopolitical, military-technical components, put into a doubt the possibility of the foreseeable future global world wars. There is an illusion of appearance of the international community to resolve the endless possibilities of local, simple conflicts. The most favorable situation seemed to appear for the United States on the world arena. However, the reality was different. A complex international system of balance of power that existed since the end of World War II, has been broken. The complexity of the transformation of the nature of wars and military conflicts in the post-Cold War era was investigated by Mark Trachtenberg - Professor, University of California. According to an outstanding American scholar there is a sustainable balance of power on the world stage in the era of the "cold war", and the loss of the balance after the collapse of the Soviet Union (Trachtenberg, 2012). L. Coser says that one of the creative functions of conflict is in maintaining a balance of power (Coser, 1957). It is necessary to take into account the constructive potential of these phenomena based on the concept of positive-functional conflict. A signal and modernized function of military conflicts leads to the resolution of contradictions, the preservation and development of the system of international relations. As M. Trachtenberg says the significant increase of wars and conflicts in the XXI century is the result of imbalance (Trachtenberg, 2012). Thus, in the post-bipolar period characterized by an imbalance of forces and increasing international conflict, there was a clear strengthening of the international influence of the United States.

Modern post-bipolar period is characterized by two opposing trends: on the one hand, the risk of a world war, an open conflict between the major powers is extremely low, on the other - the number of peripheral interstate (the 
Afghan-Pakistani conflict, 2007 - up to the present) and domestic (the conflict in Syria, 2011 - up to the present) conflicts has increased. Approximately 50 countries want to have the territories of their neighbors. The American researcher Daniel Pipes informs that in Africa there are 20 such cases, in Europe - 19, in the Middle East - 12, in Latin America - 8 (RIA-Novosti, 2008).

The existence of the so-called "a secret component" is characteristic for many modern military conflicts. In such conflicts participation of the USA and their allies carries not a direct, open, but a latent character. The White house, possessing a high rank in the conflict, according to the pursued interests, acts not as the direct opponent, but as the organizer, the helper, the initiator or the intermediary of the process. The military conflicts of the post-bipolar period except latent interests of the leading actors of the world community, have quite "classical" contradictions. The interethnic (The Croatian and Bosnian conflict, 1992-1994), religious (numerous manifestations of Islamic fundamentalism), territorial (the conflict between the Republic of Mali and the Republic of Burkina Faso 1985), imperious (The Ukrainian conflict of 2014) and economic contradictions (this component is present practically at all modern conflicts) can be referred to this number. Most often in one conflict it is possible to observe an interlacing of various contradictions, that shadow participants successfully use. A striking example of it is the Palestinian-Israeli conflict where behind each of the parties there is the whole group of conditionally latent participants including the USA pursuing their interests. Thus, for the post-bipolar period first comes the problem of growth of peripheral (regional and local) interstate conflicts, their prevention and solution. The main complexity of process of settlement of the modern conflicts including asymmetric ones is in above-mentioned balance of forces concerning acute contradictions about the question of defining the role of the chief performer among the UN, the USA, NATO, and members of the EU. The decision of the USA to attack the positions of fighters of "The Islamic state" (2014) in the territory of the sovereign state of Syria without consent of the Syrian government and the decision of the UN Security Council, i.e. without the international legitimacy what the Foreign Minister of Syria openly declared during the 69th session of the United Nations General Assembly in New York (the Kommersant, 2014) tells about positioning the USA as an undisputed world leader.

The Iraqi war can be a typical example of the conflict with participation of the USA in the post-bipolar world. There are a lot of researches on the given problem in modern political science. Moreover, many encyclopedias describing events of the American-Iraqi opposition with a scrupulous accuracy are written(Mockaitis 2013). In the majority of cases these works serve as justification of the idea that the conflict is the result of a contradiction between democratic and authoritative states. According to the authors the ideological aspect of contradictions comes first. But it is only partly right. A complex, secret nature of the American-Iraqi military conflict is reflected in the book of the influential American publicist Charles Koyot. A wide teoretiko-historical background of the war in Iraq is shown in the book. (Coyote, 2013).

As an additional reason to military intervention, one can specify the economic component - the presence of Iraqi oil fields, and the reluctance of Saddam Hussein to subject national interests to the will of Washington, as well as a desire of George Bush to succeed in presidential elections of 2004. Thus on the example of the Iraq war, we can trace the intertwining of economic, territorial, governmental, inter-ethnic and inter-strategic interests that formed the basis for modern wars and military conflicts.

\section{Methodological Framework}

Legitimization of military conflicts between the democratic and authoritative states for the purpose of changing of the regime, is aimed at achievement of progressive aims and tasks, under loud statements in protection of human rights, prevention of distribution of weapons of mass destruction or fight with terrorism. As a confirmation it may be taken the war in Afghanistan in which according to the USA, they combat not against the Afghan state or the people, but against the terrorist threat of Afghanistan in the face of Al-Qaeda and Taliban. Barnetta Rubina one of the leaders of experts on "the Afghan question", the director of the Center of the international cooperation of the New York university, told in detail about it in a new monograph. The author, in fact, separates the Afghan terrorists from the Afghan people, and the authoritarian "talibansky" regime from the Afghan statehood, accurately bringing to thought that the interstate conflict between the USA and Afghanistan does not exist. B. Rubin considers military actions of the USA and anti-terrorist coalition allies at the beginning of the 2000th years as an "effort of Afghanistan rescue" (Rubin, 2013). The same model is used in the conflict to Syria.

Through a prism of the Afghan war we can observe one more side of the modern military conflicts. The majority of them represent collision of interests on distribution of tendencies of globalization, on the one hand, and aspiration to keep the identity and independence by discharge of globalization processes, on the other. The 
states in this sense, undoubtedly, are the engine of globalization processes in policy, economy and even culture. The conflict of globalization and tradition against war is well shown in memoirs of participants of events in Afghanistan. For example, John Cook - the colonel of coalition forces and the American military adviser in Kabul, in the book devoted to the stay in Afghanistan speaks about such conflict more than frankly. It gives the characteristics of breeding structure of the Afghan society and thinking corresponding to it which, despite all the efforts could not be changed. Moreover, Cook convicts in a provoking tone "aggressive essence of Islam" as a threat for the USA. (Cook, 2012).

In general all modern conflicts on the international scene can conditionally be divided into two groups: the interstate conflict between the unequal parties (when a strong state and their coalition act as opponents) and interstate conflicts for various resources. The modern United States take part in and initiate as well as the interstate conflicts, so asymmetric interstate conflicts with rogue states which proceed mainly in peripheral regions and against the background of development of processes of globalization and strengthening of interdependence of the states involved in them. The main reasons for a tendency of prevalence of the interstate conflicts over "classical" wars, the parties of which are independent states one can call the development of the nuclear weapons and control over nuclear armament (as a result the number of nuclear powers is limited, and war between them is almost impossible in connection with its irreversible consequences); increase of number of states with democratic and liberal norms; necessity of new territories occupation; development of processes of globalization. However these tendencies don't exclude possibility of the asymmetric conflicts.

But not always strategic interests of the White House are concerned with peripheral, non-democratic regions of the world. In the XXI century the conflicts with participation of the States can arise in the countries, quite safe from the international legal point of view. In a theoretical plan it is important and necessary to separate wars with direct participation of the USA from the interstate military conflicts retaining strategic interests of the White House. Thus it is necessary to notice that the state of peace between democracies, according to a number of researchers, is possible only on condition of perception by the states of each other as democratic ones (Brown, M. E. et al., 1998). What happens if the USA don't agree to recognize any the state as that? That is from the international- legal point of view democracy exists, but in the American understanding it does not. The analysis of events of "color revolutions" in the former Soviet Union, and also "the Arab spring" in the Middle East will help to give the answer to this question. As the main reasons of the modern interstate military conflicts may be considered, nationalism, religious fundamentalism, terrorism and organized crime, exhaustion of natural resources, change and weakening of functions of the state, increase of separatism tendencies in them. Thus, as the most common cause of the conflicts it is possible to designate fight for imperious, economic, natural and other resources. We could observe the above designated tendencies leading to emergence of the conflicts at the beginning of the XXI century in development of such states as Georgia, Ukraine, Egypt, Tunisia and some other. However the existence of tendencies is not enough for initiating the interstate military conflict. The most important characteristic of escalation is the presence of indirect participants - instigators or organizers, judges or intermediaries as whom the USA act in the most active way in the majority of the interstate military conflicts today. Characteristic feature of the modern interstate conflicts is their growth of borders of the state, regeneration in more extensive collisions and involvement in them of the whole region. "The internal" characteristics of such conflicts are violation, "a total dehumanization", a wide use of children and women in military operations, acts of terrorism against civilians, deprivation of civilians of conditions for normal existence. In general the vertical accelerated escalation (sharp growth of intensity of the conflict), and horizontal (distribution of the conflict out of borders of the country) are peculiar to such conflicts.

The analysis of the modern conflicts parties shows that in their quality non-state (substate) actors and the international organizations even more often act (NATO, the EU, the UN). The increase in number of non-state actors (criminal groups, the nationalist, religious, terrorist organizations, diasporas, insurgent groups, irregular paramilitary forces, mercenaries) is explained by weakening of the state, including thanks to actions of the mentioned actors. Whether it be its inability to guarantee safety of citizens, destruction of the state monopoly for use of military force, reduction of a role in production and distribution of resources it is possible to refer broad social transformations, globalization processes, activity of the terrorist organizations, influence growth to number of the reasons of change of functions of the state (especially on the weak states) transnational military economies and corporations. As a result of influence of above-mentioned factors non-state actors have legal, political, financial opportunities. Characteristic feature of the modern interstate conflicts is their growth for borders of the state, regeneration in more extensive collisions and involvement in them of the whole region. It is possible to carry their duration, bitterness, "a total dehumanization" to "internal" 
characteristics of such conflicts - wide use in military operations of children and women, carrying out acts of terrorism against civilians, deprivation of civilians of conditions for normal existence. In general to such conflicts peculiar as the vertical accelerated escalation (sharp growth of intensity of the conflict), and horizontal (distribution of the conflict out of borders of the country). According to the analysis the parties of the modern conflicts are the non-state (substate) actors and the international organizations (NATO, the EU, the UN). The increase in number of non-state actors (criminal groups, the nationalist, religious, terrorist organizations, diasporas, insurgent groups, irregular paramilitary forces, mercenaries) is explained by weakening of the state, due to the actions of the mentioned actors. To the reasons of changing of the functions of the state whether it is inability to guarantee safety of citizens, destruction of the state monopoly for use of military force, reduction of a role in production and distribution of resources we can refer broad social transformations, globalization processes, activity of the terrorist organizations, influence growth to number of the reasons of change of functions of the state (especially on the weak states) transnational military economies and corporations. As a result of influence of above-mentioned factors non-state actors have legal, political, financial opportunities.

\section{Results}

In the XXI century for new international system the interstate and asymmetric conflicts of the religious and ethnic and economic nature are on the center of attention. Despite the fact that the conflicts have a number of peculiar features, their intrinsic characteristics - dynamics (including a preliminary, preparatory stage, incident, stages of conflict interaction and settlement or a resolution of conflict, a post-conflict stage), structure, interests of the parties as a settlement source, remain stable. The developed international system of prevention, constructive political settlement and management of the conflicts containing a military component (strategies of coercion to the peace, peacekeeping, demonstrations of force, disarmament and control over arms supplies to warring parties, prosecution and punishment of war criminals) and not military (a resolution of conflicts through the international arbitration and legal proceedings, deliveries of humanitarian aid and its distribution, actions of police forces of the UN), will be supplied with careful studying of new conflicts, their context and dynamics, interests, values, opportunities, motives and identifications of the parties from humanitarian and pragmatic bases.

\section{Discussions}

Role of non-state and indirect participants including the USA in spreading the given tendencies by various researchers is estimated differently. So, the head of the Center of comparative Middle Eastern researches of University of the Southern Denmark - professor Dietrich Jung accuses non-state participants of expansion of the conflicts. "Internal conflicts are the result of the international intervention which happen for the sake of establishment and development of market structures and democracy", - D. Jung claims (Jung, 2003). Identification of a role of the USA as an indirect participant, undoubtedly, allows to see a complete picture of nature, dynamics and consequences of the conflicts with their participation.

The western political science doesn't deny the crucial role was played by the American technologies and the organizations financed by the USA during the events in Tunisia and Egypt. Among such strategists we can mention the famous American political scientist, professor of the Massachusetts university Jean Sharp. In his work "From dictatorship to democracy" he suggests everyone to examine 198 methods of "nonviolent" fight against the existing government (Sharp, 2012). For practical use of these methods and with a direct participation of the American intelligence services the special research center called by Albert Einstein's Institute was created. In 2011 the influential American edition "New York Times" made journalistic investigation by the results of which they came to a conclusion that Sharp is "the ideological father" and one of inspirers of the Arab spring (Stolberg, 2011). It is known that its works were translated into the Arabic language, and the movement "Muslim Brotherhood" uploaded 198 methods of Sharp to the website for general acquaintance and acceptance to action. The events in the Ukraine and in Georgia were not spontaneous ones, but carefully prepared within several years, according to American strategic recommendations. As Daniel McAdams - the executive director of Institute of Ron Paul for the peace and prosperity claims, all color revolutions are sponsored directly by the USA, so "Washington tries to make pressure upon political regimes" (the Look. Business newspaper, 2013). In this regard the recent statement of the president V. V. Putin about need to carry out the analysis of all color revolutions, including the latest events in the Ukraine is extremely actual. "We have to make such analysis to protect our citizens from an arbitrariness of various ultras, from an arbitrariness of terrorist elements and people with extreme views" (Forbes, 2014). In this article the Russian point of view on the role and place of the USA in modern wars and the military conflicts is reflected, this aspect isn't characteristic, in general, for the western political science and wasn't considered in the previous 
researches.

\section{Conclusion}

Thus, as the most real reason of involvement of the USA in numerous wars and military conflicts can be mentioned the struggle for imperious, economic, natural and other resources. Besides, if occupation of new territories now isn't a leading task, the question of possession, accumulation, control and distribution of natural resources is the first on the agenda. In the theoretical plan the tendency of reduction of number of classical wars with simultaneous increase and complication of the content of the interstate conflicts led to replacement of the concept "war" with the concept "conflict". War is only one case of such complex phenomenon as conflict.

\section{Acknowledgments}

The work is performed according to the Russian Government Program of Competitive Growth of Kazan Federal University.

\section{References}

Brown, M. E., Cote, O. R., Lynn-Jones, S. M., \& Miller, S. E. (Eds.). (1998). Theories of War and Peace: An International Security reader. Cambridge: The MIT Press: 604.

Cook, J. (2012). Afghanistan: The Perfect Failure - A War Doomed by the Coalition's Strategies, Policies and Political Correctness. New York, NY: BookBaby: 236.

Coser, L. (1957). Social Conflict and the Theory of Social Change. The British Journal of Sociology, 8(3), 197-207. http://dx.doi.org/10.2307/586859

Coyote, Ch. (2013). IRAQ WAR 2003: What Really Happened Behind The Scenes: The Story Of The Greatest Blunder In American. New York, NY: Coyote Report: 364.

Forbes. (2014, March 27). Putin prizval ogradit' grazhdan Rossii ot "tsvetnykh revolyutsi". Retrieved February 25, 2015, from http://www.forbes.ru/news/253121-putin-prizval-ogradit-grazhdan-rossii-ot-tsvetnykh-revolyutsii

Jung, D. (Ed.). (2003). Shadow Globalization, Ethnic Conflicts, and New Wars: A Political Economy of Intra-State War. London: Routledge: 9-26. http://dx.doi.org/10.4324/9780203216965

Kommersant. (2014, September 27). Oni skazali, chto budut nanosit udary tri goda. Retrieved February 26, 2015, from http://www.kommersant.ru/doc/2577621

Mockaitis, T. R. (Ed.). (2013). The Iraq War Encyclopedia. Santa Barbara, CA: ABC-CLIO: 542.

RIA-Novosti. (2008, August 25). Neuregulirovannye territorialnye spory v mire. Spravka. Retrieved February 26 , 2015, from http://ria.ru/politics/20080826/150695029.html?id=

Rubin, B. (2013). Afghanistan from the Cold War through the War on Terror Hardcover. Oxford: Oxford University Press: 528.

Sharp, G. (2012). From Dictatorship to Democracy: A Conceptual Framework for Liberation. New York, NY: New Press: 160.

Stolberg, S. G. (2011). Shy U.S. Intellectual Created Playbook Used in a Revolution. The New York Times, 17 February. $\quad$ Retrieved from http://www.nytimes.com/2011/02/17/world/middleeast/17sharp.html?pagewanted=all\&_r=0

Trachtenberg, M. (2012). The Cold War and After: History, Theory, and the Logic of International Politics. Princeton. Princeton University Press: 336.

Vzglyad. Delovaya gazeta. (2013, July 29) The USA ustraivayut tsvetnye revolutsii s pomoshchyu natsionalistov. Retrieved February 25, 2015, from http://vz.ru/news/2013/7/29/643241.html

\section{Copyrights}

Copyright for this article is retained by the author(s), with first publication rights granted to the journal.

This is an open-access article distributed under the terms and conditions of the Creative Commons Attribution license (http://creativecommons.org/licenses/by/3.0/). 